\title{
INTELIGIBILIDADE E DOAÇÃO: \\ UMA LEITURA DE HUSSERL
}

\author{
Mafalda Blanc ${ }^{I}$ \\ Universidade de Lisboa
}

Mesmo se muito distante da percepção sensorial, temos uma espécie de percepção dos objectos da teoria dos conjuntos [...] e eu não vejo porque deveriamos menos confiar neste tipo de percepção, quer dizer, na intuição matemática, do que na percepção sensorial que nos permite construir teorias físicas. [...] Todavia, não se segue daqui, como afirmava Kant, que os dados deste tipo, porque não os podemos ligar a acções sobre os órgãos dos sentidos, sejam dados subjectivos. Pelo contrário, eles poderiam representar um aspecto da realidade objectiva, e a sua existência poderia dever-se a um outro tipo de relação entre nós e a realidade do que as sensações. ${ }^{2}$

\section{A intenção filosófica de Husserl: a crise de sentido e o projecto de uma reforma da razão}

Do princípio ao fim do seu percurso um mote principal percorre o pensamento de Husserl determinando aquele que é o seu projecto, a sua intenção filosófica fundamental, imprimindo-lhe o tom trágico e urgente de uma reforma radical e cabal da razão, capaz de instaurar um novo começo para o conhecimento a partir de um ponto de vista absoluto. ${ }^{3}$ Ele concerne a crise de

\footnotetext{
Dedico este artigo à memória querida de meu mestre João Paisana, que me introduziu no estudo da Fenomenologia e a Pedro Alves, estimado colega e amigo, que me tem incentivado e apoiado no árduo estudo de Husserl.

2 Kurt Gödel, Texto extraído da segunda edição da obra "O que é o Problema do Contínuo de Cantor", a partir da revista Pour la Science (ed. franc. de Scientific American), $n^{\circ} 20$, especialmente consagrado a Gödel, Ag.-Nov. 2004, p. 38.

3 Ed. Husserl, Philosophie als strenge. Wissenschaft, V. Klostermann, Frankfurt a. Main, 1965, pp. 65-67: "Die geistige Not unserer Zeit ist in der Tat unerträglich geworden. [...] Es ist
} 
sentido que vem afectando a humanidade europeia enquanto existência espiritual fundada em e pela razão, isto é, nascida e animada pelo ideal helénico da filosofia e reflecte-se, como crise da racionalidade, na descrença crescente quanto à possibilidade de um conhecimento teorético omnienglobante do todo do mundo e da vida. ${ }^{4}$

Com efeito, a crescente formalização do instrumento matemático na modernidade juntamente com a promoção de um modelo positivista de ciência, baseado na análise objectiva dos factos e na sua manipulação operatória através do simbolismo algébrico, contribuiria largamente, com o menosprezo em relação a tudo o que se refere ao âmbito da subjectividade, para o obscurecimento e deturpação do sentido das idealidades que informam, a título normativo, as verdades da ciência e da moral, contribuindo para o cepticismo crescente em relação à sua absoluta validade. Este, já implícito na perspectiva empirista do naturalismo cientista, ver-se-ia reforçado no século dezanove pelo psicologismo e o historicismo, duas formas distintas mas complementares de relativismo, isto é, de contextualização e condicionamento externo das ideias. $^{5}$

Por conseguinte, para Husserl, a crise de sentido de que enferma a cultura europeia e que se reflecte ao nível da acção na indeterminação das possibilidades e dos fins, sendo uma crise de valores, releva da racionalidade e é como tal que tem de ser confrontada e solucionada. Para ele, o problema reside no estatuto das idealidades, na legitimação credível da validade absoluta que, a seu ver, de direito reclamam para si enquanto princípios normativos da moral e da ciência e condição de um conhecimento a priori e apodíctico, mas que no entanto, sob o influxo dos factores atrás por nós apontados, se tornou entretanto problemática e relativa. A solução passa, a seu ver, por uma crítica da razão, isto é, por um exame detalhado dos fenómenos cognitivos tal como eles se dão a conhecer de modo intuitivo a uma visão imanente. ${ }^{6}$

Fenomenologia é, por isso, o nome que toma para Husserl a forma correcta e credível de gnoseologia, que precede, a título de condição de possibili-

sicher dass wir nicht warten können. [...] so gibt es gegen alle ähnlichen übel nur ein Heilmittel: wissenschaftliche Kritik und dazu radikale [...]".

4 Conf. do mesmo, Die Krisis der Europäischen Wissenschaften und die traszendentale Phänomenologie, (Husserliana, VI), M. Nijhoff, Haag, 1954, § 3, p. 5 e segs. e, em anexo II, a célebre conferência "Die Krisis der Europäischen Menschentums und die Philosophie", pp. 314 e segs.

5 Veja-se Philosophie als strenge Wissenschaft, ed. upra-citada, p. 13 e segs. no que concerne o naturalismo e o psicologismo, e p. 49 e segs. para a crítica do historicismo.

6 Veja-se Ibid. e, do mesmo, o texto das cinco lições intitulado Die Idee der Phänomenologie, (Husserl., II), M. Nijhoff, Haag, 1950, $3^{\mathrm{a}}$ lição, p. 52: "In der Richtungen auf die Kritik der Vernunft, der theoretischen nicht nur, sondern auch der praktischen [...] die Feststellung der selbst zugebenden prinzipiellen Formen und Sachverhalte und mittels dieser Selbstgegebenheiten die Realisierung, die Auswertung und Bewertung der mit dem Anspruch auf prinzipielle Bedeutung auftretenden Begriffe und Gesetze der Logik, der Ethik, der Wertlehren." 
dade, toda a forma possível de filosofia científica e sistemática. Compete-lhe a justificação da pretensão à verdade que reclamam para si conceitos e juízos no seu visar de um objecto transcendente através de um visar significativo. Ela passa, como veremos, pela restituição das idealidades que os informam essências, categorias - às suas fontes intuitivas ụ́ltimas e inconcussas e que são evidências adequadas tiradas da própria subjectividade.

Crise de sentido, crise da razão nos seus fundamentos, reforma da racionalidade através da restituição da formalidade dos conceitos e categorias às suas fontes intuitivas - eis o eixo programático de referência que norteia a realização gradual do intento reformista deste autor, conferindo coerência e homogeneidade ao seu pensar, mesmo quando os caminhos trilhados, as soluções encontradas nem sempre se apresentam, como veremos, como os mais adequados ou conformes.

\section{A proposta da Fenomenologia: o retorno às fontes intuitivas da razão}

Jamais questionado ou sequer demonstrado porquanto se auto-legitima na sua ultimidade, o pressuposto capital do pensamento de Husserl, que lhe permite levar a cabo o seu intento reformista de legitimação da aprioridade do conhecimento e de restituição à filosofia do seu campo temático enquanto metafísica, consiste na valorização da intuição como traço essencial da racionalidade. Longe, na verdade, de a restringir ao plano empírico da percepção, como o empirismo e Kant na redução que fizeram das ideias ao elemento lógico e nocional, vai Husserl situá-la no cerne mesmo da actividade racional, considerando, com Descartes, que o que caracteriza a inteligência como razão (Vernunft) não é o mero intentar significativo de conceitos e generalidades, à maneira da indução abstractiva aristotélico-tomista, mas a captação num acto concreto de realidades concretas, trate-se de singularidades empíricas ou de essencialidades. O nosso autor retoma, assim, a grande inspiração do platonismo e do pensamento grego em geral, segundo a qual pensar consiste em intuir (noein), ter presente como dado (Gegebenheit) aquilo que é visado, ou seja, a coisa, o ente, numa palavra, o ser. ${ }^{7}$

De modo que uma apreensão directa e imediata da própria coisa no seu ser é possível, mesmo se nem sempre adequada ou perfeita, enquanto tal intuir sempre difere da mera intenção simbólica vazia. Ela constitui mesmo, para Husserl, a pedra de toque da verdade, a norma, a medida que dá sentido a todo

7. Veja-se, a este propósito, o artigo de L. Brunschwicg, "La Pensée intuitive chez Descartes et les Cartésiens", Rev. de Métaphysique et de Morale, XLIV, 1, 1937, pp. 1-20 e, ainda, Parménides, "Da Natureza", frags. 3 e 8, 34-36 in Diels, Parménides Lehrgedicht, Berlim, 1897. 
o conhecimento. ${ }^{8}$ Negá-la é cair nas malhas do cepticismo, retirar-se, sem remissão possível, a via de alcance da realidade; é ficar entregue ao entendimento (Verstand), faculdade, ligada à imaginação, das ideias gerais e dos princípios abstractos, com a qual se não deixa confundir a razão na pureza da sua essência intelectual. ${ }^{9} \mathrm{O}$ filósofo pode então enunciar, no texto programático das Ideen, o tema, o princípio dos princípios (Prinzip aller Prinzipien) da Fenomenologia: "[...] que toda a intuição doadora originária é uma fonte de direito para o conhecimento, que tudo o que se nos oferece na 'intuição' originária (por assim dizer na sua realidade corporal) deve simplesmente ser tomado tal como se dá."10

Sendo, portanto, pensar intuir, acolher no que aparece o manifestar-se do próprio ser, então a extensão deste pensar, desta visão é imensa: ela esprai-se desde o âmbito do ser real dado à percepção numa intuição transcendente, às estruturas que o informam como essencialidades (species), e do domínio categorial ou formal da possibilidade ao âmbito interno da subjectividade, dado à reflexão numa intuição imanente e adequada. ${ }^{11}$ Abre-se assim à Fenomenologia um vasto leque de tarefas que vão desde a auto-crítica da razão como gnoseologia à investigação concreta do "logos" dos fenómenos na sua unidade e conexão estrutural.

Husserl regressa assim à evidência originária da filosofia grega e isso em dois momentos principais. Num primeiro, com a recusa do carácter formal da racionalidade que afecta de esterilidade o pensamento moderno, e a que contrapõe uma concepção não psicológica, intencional, do pensar como relação a conteúdos ideais que, longe de perfazerem representações ou simulacros, se reportam ao próprio ser. Num segundo momento, pela convicção de que o âmbito do aparecer, o campo da fenomenalidade tem uma inteligibilidade intrínseca que pode ser explicitada e descrita: um teor categorial que regula e articula a ordem interna dos fenómenos e uma estrutura eidética que determina o seu tipo e à qual se reduz o seu aparecer. ${ }^{12}$ Uma filosofia primeira parece, deste modo, de novo possível e isso na forma inovadora de uma fenomeno-

8 Como se pode ler em Die Idee der Phänomenologie, IV Vorl., ed. supra-cit., p. 61: "Absolute Gegebenheit ist ein Letztes."

9 Ibidem, p. 62: "Schauende Erkenntnis ist die Vernunft, die sich vorsetzt, den Verstand eben zur Vernunft bringen."

${ }^{10}$ Ideen zur einer reiner Phänomenologie und phänomenologischen Philosophie I, (Husserl, III), M. Nijhoff, Haag, 1950, § 24, p. 52: "[...] dass jede originär gebende Anschauung eine Rechtsquelle der Erkenntnis sei, dass, alles, was sich in der 'Intuition' originär, (sozusagen in seiner leibhaften Wirklichkeit) darbietet, einfach hinzunehmen sei, als was es sich gibt [...]."

11 Atente-se, por ex., em Die Idee der Phänomenologie, IV ${ }^{a}$ Vorl., ed. supra-cit., p. 63 o trecho seguinte: "Es gibt vielfältige Modi der Gegenständlichkeit und mit ihnen der sogennanten Gegebenheit [...]."

12 Veja-se a seguinte passagem das Logische Untersuchungen, $2^{\circ}$ vol., $1^{\mathrm{a}}$ p., $I^{\mathrm{a}}$ Inv., $\S 28,4^{\mathrm{a}}$ ed., M. Niemeyer, Halle, 1928, p. 90: "Alles, was ist, ist 'an sich' erkennbar, und sein Sein ist inhaltlich bestimmtes Sein, das sich dokumentiert in den und den 'Wahrheiten na sich'. Was ist, hat seine an sich fest bestimmten Beschaffenheiten und Verhältnisse, $[\ldots] . "$ 
-logia, isto é, como estudo descritivo da estrutura apriórica do ser no modo como ela se articula em domínios e regiões hierarquizados segundo graus distintos de universalidade, que vão desde as essências materiais às formais e destas ao próprio ser, conceito de máxima amplitude ou extensão. ${ }^{13}$

Porém, como veremos, as coisas não são assim tão simples. Com efeito, o que Husserl denomina 'ser' e que tem um estatuto indeterminado, entre o realismo e o idealismo, ao nível das "Investigações lógicas", é por ele mais tarde interpretado - a partir de 1907, com o texto "A Ideia de Fenomenologia" - como objectividade (Objektivität). Com isso o filósofo transpunha para o solo moderno da subjectividade a experiência filosófica grega do aparecer. A esta nova luz, o que aparece e se dá a intuir é algo que o próprio sujeito constituiu através das suas operações como um idêntico reconhecível. A experiência interna e, em última instância, o fluxo auto-constituinte da temporalidade passa doravante a perfazer, como veremos, o horizonte de referência da fenomenalidade. Em que medida, até que ponto isso é suficiente para legitimar a validade do conhecimento - questão prioritária, lembremo-lo, do intento huserliano - sem que alterações profundas na concepção de aprioridade não venham a tornar-se necessárias, é o que teremos de averiguar no decurso das nossas reflexões.

\section{A estrutura da consciência}

A realidade, o ser precede a consciência; e no entanto, na sua condição de ser dada que a determina como fenómeno, ela deve dar-se, aparecer a alguém, a um sujeito. Não sendo este, porém, um receptor passivo de dados, a relação que mantém com a realidade traduz-se num conjunto de actos que a sua consciência cumpre e através dos quais forma, constitui ou torna presente para si o fenómeno, que nem por isso é ilusório, pois que inseparável do ente em si, de que é a manifestação. Na verdade, desde a sua aparição que de algum modo o conhecemos, embora o fenómeno nem sempre o manifeste tal como é, surjam sempre decepções ou inadequações, próprias afinal da distância, da diferença que há entre o conhecer e o ser. Este intervalo, que pode distanciar-se muito da verdade, é algo que o senso comum e a ciência aceitam sem controvérsia e que intentam a seu modo corrigir através de uma análise crítica do conhecimento, que procede à destrinça, nos actos, entre o subjectivo que concerne a aparência e o que se reporta ao objecto transcendente e perfaz o verdadeiro aparecer.

${ }^{13}$ Sobre as regiões ontológicas, o texto de referência essencial é $I$ deen $I, 1^{\text {a }}$ secção, $1^{\circ}$ cap., $\S \S 9-17$, ed. supra-cit., pp. 23-39. Veja-se ainda, a propósito do mesmo, do autor Cartesianische Meditationen und Pariser Vorträge, (Husserl. I), M. Nijhoff, Haag, 1950, § 29, pp. 97-99. 
Husserl, porém, na descrição que fez da relação gnoseológica e que tem um carácter abstracto, privilegiou o conhecer sobre o ser, a reflexão sobre o saber à apreensão do objecto a conhecer, a gnoseologia sobre a ontologia, invertendo a autonomia e prioridade essenciais do ser sobre o conhecer, para que aliás já aponta a orientação primária para o objecto do acto noético transcendente. Com efeito, de estatuto indeterminado quanto à sua verdadeira natureza nas "Investigações lógicas", o objecto intencional vai definir-se, após a primeira edição daquela obra, não como algo pré-existente, um conteúdo já dado a que o acto se reportaria na sua intentio objectivante, mas como uma unidade que se constitui no acto, um pólo idêntico de intenções, a que a consciência se reporta numa variedade de modos. ${ }^{14}$ Destarte e quiçá traindo as melhores intenções da sua fenomenologia, vai o filósofo entrincheirar-se nas fileiras do idealismo transcendental e lógico, considerando com este que o objecto, longe de depender do ser e consistir na sua representação provisória e aproximada, se põe e configura pela e na actividade gnoseológica e lógica do sujeito.

É assim que, na abordagem que fez da consciência a partir de Brentano como um conjunto de vividos intencionais unidos no fluxo da temporalidade actos noéticos que, na sua constitutiva referencialidade ao objecto, podem ser de teor significativo ou intuitivo - vai o filósofo privilegiar os primeiros, considerando a intuição como um momento dependente e subordinado, um recheio ou mero preenchimento da significação, mesmo se, por outro lado, ela consigna o momento fundante da verdade, em que a coisa se dá aí, por assim dizer"na sua corporalidade". ${ }^{15}$ Desta feita, esperamo-lo mostrar, o mundo aparece mais visado do que dado e o fenómeno, o objecto aparecente determina-se como o produto de uma constituição subjectiva. Esta, que torna possível o aparecer da coisa, não é, porém, uma criação absoluta, mas uma espécie de posição (Stellung), que inclui não só o acto de visar como a própria visão, o intuir.

Debrucemo-nos então, mais detalhadamente, sobre a estrutura complexa destes actos.

14 Sobre o estatuto indeterminado do objecto intencional, atente-se, por ex., na seguinte afirmação das Logische Unters., V ${ }^{\mathrm{a}}$ Inv., § 14, pp. 386-387: "Erlebnis ist das die Welt-Meinen, die Welt selbst ist der intendierte Gegenstand. Für diese Untersheidung ist es, wie ich noch ausdrücklich betonnen will, gleichgültig, wie man sich zu den Fragen stellt, was das objective Sein, das wahre, wirkliche An-sich-sein der Welt oder eines beliebigen sonstigen Gegenstand ausmacht [...]."

15 Para a definição de consciência, veja-se Ibidem, §§ 1-2, pp. 345-350. Sobre a distinção entre actos significativos e intuitivos, conf., por ex., Ibid., I Inv., $\S \S 13-14$, pp. 49-51. 


\subsection{Intencionalidade e significação: a esfera da idealidade}

Husserl parte da noção de vivido intencional de seu mestre Brentano, segundo a qual o que constitui um acto psíquico é a relação ou orientação da consciência para um conteúdo ou objecto imanente, não real, de teor mental ou meramente intencional. Nesta relação, qualquer que seja a sua modalidade e ela apresenta-se variada (representações, juízos, sentimentos), a representação é sempre o elemento imprescindível e determinante, pois é por ela que se efectiva a relação da consciência ao objecto. ${ }^{16}$

Adoptando este esquema geral, o discípulo, empenhado em mostrar, com Bolzano ou Frege, a validade da esfera lógica do conceito e por este advertido contra o psicologismo, temendo o subjectivismo, a dissociação entre o espírito e a realidade inerentes a uma filosofia da representação, vai entender esta última como um momento subordinado do acto e interpretá-la no seu teor intencional a partir da significação (Bedeutung). ${ }^{17}$ Transcendente aos actos de enunciação e expressão em que se inscreve, permitindo a comunicação e o intercâmbio de ideias, é por esta que o acto perfaz a referência directa ao objecto, de que constitui no entanto um momento lógico distinto. ${ }^{18} \mathrm{Com}$ efeito, imprimindo ao acto um sentido objectivo de apreensão (objektive Auffassungssinn), a significação orienta, direcciona a consciência para a captação do objecto sob tal ou tal aspecto, abrindo caminho à sua presentificação, possibilitando, de forma perspectivada embora, a sua apreensão intuitiva como um todo, uma unidade já informada categorialmente e com a sua própria determinação. $^{19}$

É todo um complexo trabalho já hermenêutico de constituição esse por que a consciência, por operações de objectivação, unificação e comparação de dados hiléticos, faz aceder aspectos e níveis do real à objectividade de uma verdade possível, que se pode conhecer na sua estrutura invariante e partilhar

16 Veja-se Logische Unters., Va Inv., cap. 1, § 2, pp. 347-350 e cap. 3, § 23, pp. 427-430.

17 Ibidem, cap. 5, § 41, pp. 493-494.

18 Ibid., I I Inv., cap. $1, \S \S 13$ e 12, p. 46: "Jeder Ausdruck besagt nicht nur etwas, sondern er sagt auch über Etwas; er hat nicht nur seine Bedeutung, sondern er bezieht sich auch auf irgend welche Gegenstände. [...] Niemals fällt aber der Gegenstand mit der Bedeutung zusammen."

Husserl evita a distinção fregeana entre sentido (Sinn) e referência (Bedeutung), pois tende a dissociar o 'sentido de apreensão' (o ‘enquanto que'/ als was) da função de reenvio como se fossem duas faces do mesmo acto doador de sentido, a que confere significação e a que orienta para o objecto. Faz assim equivaler a 'referência' de Frege ao 'sentido', pois para ele é sempre através do que uma expressão significa que ela adquire um sentido objectal. Veja-se a discussão do tema em M. Dummet, Ursprung der analytischen Philosophie, Suhrkamp, Frankfurt a. Main, 1988, cap. V (trad. franc., Gallimard, Paris, 1991, pp. 53 e segs.). dem Akte als dieser und kein anderer gilt, sie ist gewissermassen der die Qualität fundierende (aber gegen deren Unterschiede gleichgültige) Sinn der gegenständlichen Auffassung (oder kurtzweg Auffassungssinn)." 
intersubjectivamente. Interpretando materiais pré-dados e reportando-os a um pólo idêntico de sentido, unificando os referentes dos vários actos intencionais e conectando os vários momentos do seu preenchimento intuitivo, ela torna presentes ou representáveis objectos e relações objectivas numa generalidade, que tanto pode ser específica como individual conforme a natureza do objecto em questão. Ao fazê-lo, contudo, introduz na sua relação ao sensível um elemento de distanciação e idealização, um excedente de sentido ideal ou categorial, que implica que em tudo o que vê e percebe sempre vise mais do que lhe é dado. É que, pela donação de sentido que efectiva no seu visar intencional do objecto, a consciência transcende já sempre a efectividade, reporta-se à instância ideal do possível, ao inteligível, por que intenta mediar a sua relação à realidade.

\subsection{Intuição e experiência fenomenológica da verdade}

De diversos modos se reporta a consciência ao seu objecto e a partir de perspectivas, sentidos noemáticos distintos; e no entanto, é possível discernir na diversidade dos aspectos ou modos do aparecer possível daquele um centro unificador, constituído por um núcleo constante de caracteres. A esta unidade de sentido, a este $x$ idêntico que faz da coisa uma realidade objectiva, dá Husserl o nome de objecto intencional (intentional Gegenstand).$^{20}$ Ele torna-se uma unidade real e não simplesmente visada, quando a sua significação, de início vazia, recebe o seu preenchimento intuitivo num ver evidente, que pode ser adequado ou inadequado. Na intuição adequada, que é também originária e consigna a ideia mesma de verdade, o objecto posto pela consciência vem dar-se em pessoa, recheando com a plenitude das suas determinações a integralidade do sentido visado. Quando, pelo contrário, a intuição transcende o dado como é o caso da percepção externa, em que há experiência directa da coisa, sem que ela jamais se dê na integralidade das suas perspectivas -, não há adequação e a consciência limita-se a ter a ideia evidente do objecto, da sua essência cognitiva. $^{21}$

Cada região de objectos tem o seu sentido próprio de evidência, motivado por certos dados originários e que pode ser adequada ou inadequada, pelo que há, como veremos, uma variedade de modos de intuição. Esta recebe o qualificativo de doadora (gebende) pelo acto de constituição que a precede e configura, a doação de sentido que o seu ver pressupõe. ${ }^{22}$ Pois, como referimos atrás, a significação com as suas formas, o seu sentido de possibilidade, modela o plano intuitivo enquanto meio universal de todo o aparecer, determinando antecipadamente o "sentido de apreensão"da coisa no seu como (in der Weise, wie), embora, por outro lado, o plano intuitivo tenha também também,

20 Veja-se Ibid., V $V^{\mathrm{a}}$ Inv., cap. 1, § 17. e Ideen I, ed. supra-cit., $4^{\mathrm{a}}$ sec., cap. 1, §§ 129-132.

21 Ibid., cap. 2, §§ 136-138.

22 Ibid., $1^{\mathrm{a}}$ sec., cap. $2, \S 24$. 
como veremos, as suas leis - leis sintéctico- $a$ priori que regem a matéria do objecto de experiência -, determinantes do aparecer dos objectos. ${ }^{23}$ Do encontro destes dois planos resultam, mostrá-lo-emos adiante, as formas categoriais.

$\mathrm{O}$ atrás citado princípio de base da fenomenologia prescreve que, à partida, toda a prestação de sentido da consciência, todo o conceito podem e devem ser reconduzidos às evidências originárias que os motivaram, a fim de não se tornarem representações sígnicas vazias. Ora, para o nosso autor, a intuição doadora originária imediata e fundante é a experiência concreta, perceptiva, da coisa aí presente, a qual é sempre consciência posicional de uma existência real. ${ }^{24}$ Daí que, em seu entender, todos os juízos, toda a lógica se devam poder deixar reconduzir a juízos de experiência, os quais se apoiam na doação imediata e antepredicativa de objectos individuais e não são senão a explicitação predicativa do seu sentido implícito. ${ }^{25}$

A intuição torna-se activa e criadora no plano inteligível das idealidades (essências, categorias, estados de coisas). Neste caso, em que a ideia, a significação nos é dada através da efectuação actual de sínteses judicativas, a intuição, que é fundada, é o acto complementar do seu preenchimento pela apreensão em pessoa da própria idealidade, enquanto esta sua presença é distinta da intencionalidade vazia do mero discurso. ${ }^{26}$

\section{A formação do saber}

Se, como atrás dissemos, a significação determina a intuição, estipulando para cada caso o 'como' do aparecer dos fenómenos, também é verdade, por seu lado, que a significação, que não é uma instância autónoma ou fundante da intencionalidade, mas um caso particular da consciência de generalidade ou de idealidade que essencialmente caracteriza aquela no seu poder objectivante e cognoscitivo, releva, na sua origem, do plano intuitivo. ${ }^{27}$ Por isso, validá-la, isto é, legitimar a verdade dos seus conteúdos ideais (conceitos, juízos) vai passar obrigatoriamente pela sua recondução às fontes intuitivas, onde certas entidades, ou melhor, estruturas (essências, categorias) se mostram elas mesmas nelas mesmas com as suas leis próprias determinantes da fenomenalidade, isto é, do manifestar-se das coisas elas mesmas.

23 Veja-se Logische Unters., III Inv., §§ 11-12 e 22-24.

24 Veja-se Logische Unters., VI Inv., $1^{\text {a }}$ sec., cap. 5, § 37 e, também de Husserl a obra Formale und Transzendentale Logik, M. Niemeyer, Halle, 1929, $2^{\text {a }}$ sec., cap. 4, §§ 83-86.

25 Conf. Husserl, Erfahrung und Urteil, Claasser Verlag, Hamburg, $2^{\circ}$ ed., 1954, introd., §§ 11-14 , onde esclarece o seu intento de realizar uma genealogia da lógica, a partir da percepção externa e do juízo de percepção.

26 Veja-se Logische Unters., VI ${ }^{\mathrm{a}}$ Inv., $2^{\mathrm{a}}$ sec., $\$ \S 45$ e 46.

27 Logisch. Unters., $2^{\circ}$ vol., I Inv., § 32, p. 101: "Die Idealität der Bedeutungen ist ein besonderer Fall der Idealität des Spezifischen überhaupt." Mais adiante acrescenta sobre o mesmo, na p. 102: "[...] seine Idealität ist die der 'Einheit in der Mannigfaltigkeit'." 
No seu teor objectivo e ideal, a significação não se apresenta, com efeito, para Husserl, como um elemento incluso, uma componente real da vivência psíquica ou como o produto subjectivo de certos procedimentos lógicos de generalização e relação - esse foi o erro do psicologismo relativista e empirista, que destruiu todo o sentido do ideal, ou de Kant, que não admitiu uma intuição intelectual -, mas como o correlato objectivo e intuitivo de certos actos intencionais. ${ }^{28}$

Convencido que só é possível mostrar a possibilidade da lógica pura e da teoria do conhecimento reconhecendo a legitimidade de objectos específicos ou gerais, ao lado dos individuais ou reais, enquanto aqueles são a condição de possibilidade de um conhecimento objectivo em geral, vai o filósofo procurar resolver a moderna crise do sentido - esse 'enigma dos enigmas'que rege a relação entre a razão e a verdade possível do ser - através de uma abordagem intuitiva e descritiva da relação gnoseológica, propondo com a sua fenomenologia uma via média original entre o psicologismo e o logicismo. ${ }^{29} \mathrm{Com}$ efeito, para ele, conceitos e proposições científicas, na medida em que são verdadeiros, devem ser a expressão da doação das coisas elas mesmas e das essências das coisas captáveis na intuição.

\subsection{Significação e consciência de generalidade}

$\mathrm{Na}$ sua primeira investigação preparatória a uma fundamentação gnoseológica da lógica pura, Husserl comę̧a por destacar na significação (Bedeutung) o elemento lógico da linguagem, pelo qual esta é expressão (Ausdruck), comunicação a outrem de um conteúdo inteligível acerca de alguma coisa. Com efeito, a significação, esclarece aí, reporta-se a certos actos doadores nos quais se constitui pela intencionalidade a referência a qualquer coisa de objectivo, que, graças à intuição, sempre pode aparecer ou, ao menos, ser presentificado (por exemplo, em imagens de fantasia). Assim, embora se constitua no seio das vivências, não se reporta ou reduz a significação ao conteúdo psíquico, variável e contingente dos actos de significar, antes se refere aos objectos desses actos, que se lhes contrapõem como unidades visadas. Prova-o

${ }^{28}$ Conf. Logisch. Unters., ibid, § 31, pp. 99-101. Sobre o empirismo, veja-se, por ex., in Form. und Transz. Logik, $\S 56$, p. 135 onde afirma: "Der herrschend gewordene Empirismus [...] war blind für die eigentümliche Objektivität aller idealen Gebilde; überall wertet er sie psychologistisch um in die jeweiligen psychischen Aktualitäten und Habitualitäten." Para a crítica geral à gnoseologia de Kant, veja-se Logisch. Unters., $2^{\circ}$ vol., VI Inv., § 66 (Husserl., XIX/2), M. Nijhoff, Haage, 1984, p. 733 onde se pode ler: "[...] Kant sich das Eigentümliche der reinen 'Ideation', der adäquaten Erschauung begrifflicher Wesen und wesensgestzlicher Allgemeingültigkeiten nie klargemacht."

${ }^{29}$ Conf. Logisch. Unters., $2^{\circ}$ vol., II Inv., introd., p. 107 e Krisis, introd., § 5, pp. 11-12: “[...] bis schliesslich das bewusst zutage gekommene Weltproblem der tiefsten Wesensverbundenheit von Vernuft und Seiendene überhaupt, das 'Rätsel aller Rätsel', zum eigentlichen Thema werden musste." 
a sua idealidade, isto é, a sua generalidade e invariância, por que constitui um conteúdo idêntico, uma unidade de validade em si, que não é nada de subjectivo, real ou transitório. Por isso, embora os actos de a visar possam diferir temporalmente entre si no mesmo sujeito ou de sujeito para sujeito, o teor cognitivo da significação permanece o mesmo - um conteúdo idêntico e invariável, a que é sempre possível regressar repetindo as mesmas operações, os mesmos processos de pensamento formadores. ${ }^{30}$

Não se deve, por isso, confundir aquilo que a asserção quer dizer com o que ela manifesta enquanto acto real de julgar: o primeiro, a unidade ideal da significação, concerne uma objectividade, enquanto o segundo depende da contingência do real psicológico subjectivo. Ora, porque a significação no seu teor ideal - reporte-se a objectos individuais ou específicos - sempre releva da generalidade, ou seja, é um exemplo dessa consciência de "unidade na multiplicidade" que distingue o intencional na sua especificidade, para a elucidar em profundidade, esclarecer o teor objectivo disso que os actos de significar emprestam aos seus objectos, há que reconstituir a sua génese, remontar às operações de ideação e relação por que a consciência noética, partindo da percepção, apresenta ou torna presentes para si instâncias ou momentos estruturantes da fenomenalidade.

Husserl distingue as significações primárias que se referem às categorias-substrato, nucleares e objectivas, de substantividade ou de adjectividade (na sua função atributiva ou relacional), de outras mais complexas, de níveis diversos, respeitantes às categorias sintácticas e que concernam quer as relações entre essências quer as formas sintácticas do discurso. E procede, na sua elucidação fenomenológica, das primeiras para as segundas, ou seja, da descrição do processo de ideação que preside à formação do conceito para o estudo das sínteses activas, isto é, desses actos de articulação e relação em que se constitui o categorial. Acompanhemos então o nosso autor nesses dois momentos principais da sua investigação.

\subsection{Abstracção e ideação: a intuição das essências}

A consciência de generalidade que suporta a significação na sua unidade ideal é um modo novo de consciência, distinto daquele que assiste à percepção, embora nele fundado, em que o que é visado e intuitivamente dado numa expressa intenção não é o individual e real, mas a espécie (Spezies), ou seja, um conteúdo geral e ideal, obtido por abstracção da variação do individual. ${ }^{31}$ Com efeito, apesar do percebido - o todo concreto do objecto ou algum dos seus momentos, se apresentar já com uma certa coesão interna, porém, na percepção, como acto simples de apreensão que é, o momento formal da unidade ainda não aparece destacado, expressamente reconhecido como forma e

${ }^{30}$ Conf. Logisch. Unters., $2^{\circ}$ vol., I I Inv., § 11, pp. 43-44.

31 Ibid., II Inv., introd., p. 107. 
determinação principal. Já, contudo, na consciência de generalidade, que suporta a significação como idealidade, o que é visado é a ideia, ou seja, o momento formal da unidade que a coisa consigna na sua especificidade. ${ }^{32}$ Ora, com a ideia, a espécie, emerge um novo tipo de objectidade, de grau lógico superior ao indivíduo que, com a sua unidade ideal de sentido, a sua identidade, vai instaurar uma relação nova da consciência à realidade, justamente aquela que, com a classificação dos fenómenos, está na base da predicação e da construção do conhecimento.

Husserl designa por abstracção ideadora o processo de indução generalizante que preside à formação dos conceitos gerais, predicados ou atributos. ${ }^{33}$ Estes são essas unidades ideais extraídas por separação dos substratos individuais como componentes estruturais seus, a partir da análise comparativa de uma série de exemplares. Não basta, com efeito, à consciência do geral a singularidade de uma percepção isolada para a apreensão do universal, pois este enquanto unidade na pluralidade, requer a variação noético-noemática do acto em exemplares arbitrários, de onde se possa extrair, por similitude, o congruente de todas as variantes. ${ }^{34}$ Uma vez concluído o processo de abstracção, de destacamento das componentes do objecto nos seus nexos de respectividade e de interdependência, torna-se então possível a ideação, que é a intuição propriamente dita da essência. ${ }^{35}$

A essência husserliana, porém, porque não funda como na tradição aristotélica a sua unidade na unidade substantiva do ser, que põe e sustém a res na existência, mas na unidade sistémica e relacional que as suas notas perfazem, só a nível formal logra garantir a coesão do objecto. E isso porque a abstracção, tal como a entende o filósofo, não sai do âmbito do categorial, percorre a série das determinações formais, sensíveis e inteligíveis, do ente sem jamais penetrar até ao seu íntimo, inteligir o acto de ser, de doação em presença, em que somente consiste a unidade na sua expressão concreta e intensiva.

De modo que o conceito de objecto em geral, a que chega Husserl na sua ontologia, é apenas o conceito mais pobre de ente generalíssimo e indeterminado, a simples entidade pressuposta pelas outras categorias, não a acção que põe e sustenta o ente concreto como sujeito. Ora, falhando o ser ao nível da sua significação substantiva, vai o filósofo igualmente deixá-lo escapar ao nível categorial na interpretação que propõe da unidade do juízo a partir da noção complexa de estado de coisas (Sachverhalt). Distinta da simples ligação

32 Ibid., § 1, p. 109: “[...] für einen Akt spezialisierenden Auffassens und Meinens [...], meinen wir nicht dieses gegenständliche Merkmal, dieses Hier und Jetzt, sondern wir meinen seinen Inhalt, seine 'Idee'."

Ibid., cap. VI, § 42, pp. 223-224.

${ }^{34}$ Conf. Erfahr. und Urteil, $3^{\mathrm{a}}$ sec., cap. II, $\S 87$, c) e segs., p. 413 e segs.

${ }^{35}$ Conf. Ideen I, § 3, p. 13 e segs. e Logisc. Unters., VI Inv., § 52, p. 691: "Im Abstraktionsakte [...] ist uns das Allgemeine selbst gegeben; wir deken es nicht in bloss signifikativer Weise $[\ldots]$, sondern wir erfassen es, wir erschauen es." 
predicativa de conceitos moleculares (a substância, a que inerem acidentes), ela refere, com efeito, não o ente concreto no exercício do seu acto de ser esse que o juízo existencial explicita antes de toda a atribuição -, mas o objecto já virtualmente formalizável, uma unidade orgânica de partes ou momentos interdependentes e co-originários.

\subsection{As condições da experiência: o 'a priori' material}

A consideração dos possíveis através da variação qualitativa, dóxica, do acto intencional vai permitir, com a destrinça dos conteúdos e seus nexos, a apreensão do objecto como um todo relacionalmente estruturado. ${ }^{36}$ A distinção entre conteúdos independentes e dependentes (selbstständige und unselbständige Inhalte) que rege, a título de determinação principal, a relação entre as partes e o todo, constitui o princípio universal de organização estrutural da experiência. ${ }^{37}$ Os primeiros, invariantes, são autónomos e constitutivos do objecto na sua concretude, o que se manifesta na consistência da coisa percebida, no facto de formar uma unidade, por contraste com a não-autonomia das partes, que lhe inerem, não como predicados mas como seus momentos constitutivos. Os segundos, variáveis ou até mesmo contingentes, mostram uma ligação, uma dependência funcional em relação áo todo e a outros momentos, que os tornam abstractos e não-essenciais. São estas distinções que, como afirma, "[...] não concernam as facticidades do nosso pensamento subjectivo", mas "[...] estão fundadas na essência pura das coisas," e "[...] que, porque existem e nós as conhecemos, nos obrigam a enunciar que um pensar que delas se afastasse seria impossível, quer dizer, que um juízo que delas se apartasse seria erróneo.",38

Husserl designa por 'sintéctico a priori' essa legalidade interna à experiência, que interliga os elementos das essências (géneros, espécies, diferenças) segundo relações de interdependência funcional, que variam com as espécies de conteúdos e lhes prescrevem complementos diversos. Na sua necessidade material, ela contrasta e contrapesa o analítico formal da significação, impondo ao pensar condições próprias de intuitividade, da penșabilidade de algo como existente. ${ }^{39}$ Com efeito, as possibilidades e impossibilidades que expressa dizem respeito às coisas (as coisas da natureza e do espírito, que são

36 Conf. Logisch. Unters., $2^{\circ}$ vol., Inv. III, § 1, pp. 226-227.

37 Ibid., § 2, pp. 228-229.

38 Ibid., §6, p. 239: "Unterschiede wie dieser, [...] betreffen nicht Faktizitäten unseres subjektiven Denkens. Es sind sachliche, im reinen Wesen der Sachen gründende. Unterschiede, die aber, weil sie bestehen und wir von ihnen wissen, uns zur Aussage bestimmen: es sei ein davon abweichendes Denken unmöglich, d.h. ein davon abweichendes Urteilen sei verkehrt."

39 Ibid., §23, p. 284: "[...] sind die für die vierschiedenen Arten von Ganzen konstitutiven Gesetze synthetisch-apriorische, im Gegensatz zu den analytisch-apriorischen Gesetzen, die zu den blossen kategorialen Formen gehören [...]." 
objecto das ciências empíricas), ao seu modo concreto ou abstracto de aparecer, de se darem a conhecer em relação a outras coisas e nas suas partes eventuais - o que a consciência interpreta, no seu teor fenomenológico, como uma legalidade intrínseca à sua objectualidade. ${ }^{40}$ Com o 'a priori material', como também é denominado, está-se, portanto, diante de uma ontologia do concreto, que impõe ao objecto condições formais da sua constituição ôntica e, à percepção, um quadro geral de visibilidade, que determina a sua representação dele independentemente das variações modais da consciência.

Sendo então a essência uma forma constitutiva e determinante da coisa que a individua e ao mesmo tempo conecta com o resto das coisas e não havendo essências isoladas mas uma hierarquia de essências interdependentes - desde as singularidades eidéticas respeitantes aos indivíduos até aos géneros mais elevados, passando pelas diferenças específicas -, pode então afirmar-se, sem escrúpulos ou exagero, que assim como a estrutura constitui a determinação principal do ser, o seu logos intrínseco e o meio universal de todas as relações, também a consciência global, a ela aferente, se perfila como uma unidade de relações hierarquizadas.

Contrariamente a Kant, para quem a consciência transcendental determina em exclusivo as condições integrais da experiência - da intuitividade e da pensatividade dos fenómenos -, Husserl, distribuindo aquelas pelos dois campos do ser e do pensar, do objecto e do sujeito, intenta restituir a palavra às coisas mesmas nas suas compossibilidades e incompatibilidades, outorgando aos fenómenos, no seu teor material estruturalmente relacionado, o direito de estatuírem as regras da sua própria inteligibilidade. De modo que a coerência do juízo, a sua verdade, - que não depende apenas das suas formas sintácticas, mas da articulação possível dos seus núcleos concretos tal como estes se dão a conhecer na experiência perceptiva como concordantes entre si - vai em última instância depender ou fundar-se na comunidade de essências que perfaz a coesão, a estruturação em rede do real, ligando mesmo aquilo que se contradiz. ${ }^{41}$ Tal é, a nosso ver, a ideia directriz que sustenta, a título hermenêutico, a afirmação lapidar do autor: "O que nós não podemos pensar não pode existir, e o que não pode existir, nós não o podemos pensar: esta equivalência define a diferença entre o conceito pregnante de pensar e o de se representar e pensar na acepção habitual e subjectiva." 42

40 Ibid., Husserl., XIX/2, §31, p. 636.

41 Form. und Transz. Logik, $\S 89$, b), p. 194: "So hat jedes ursprüngliche Urteilen in seinem Inhalt [...] Zusammenhang durch den Zusammenhang der Sachen in der synthetischen Einheit der Erfahrung, auf deren Boden es steht."

42 Logisch. Unters., $2^{\circ}$ vol., III ${ }^{a}$ Inv., § 6, p. 239: "Was wir nicht denken können, kann nicht sein, was nicht sein kann, können wir nicht denken - diese Äquivalenz bestimmt den Untershied des prägnanten Begriffes Denken von dem Vorstellen und Denken im gewöhnlichen und subjektiven Sinn." 


\subsection{As condições da experiência: o 'a priori' formal}

\subsubsection{A gramática pura da significação}

Condições da experiência há-as também e principalmente, já o sabemos, do lado da consciência intencional, não apenas e em primeiro lugar no domínio estrito e já cognitivo do entendimento judicativo, nas formas que o regulam como predicação, como afirmara a filosofia transcendental clássica, mas ainda no âmbito mais vasto e antecedente da significação, do discurso, em que ele sempre se expressa e articula como um pensar significativo. Com efeito, como já antes reconhecera Humboldt, a língua, na sua estrutura, aparece para Husserl com um poder de constituição próprio e originário em relação ao pensamento. É que longe de ser um instrumento morto de expressão, de articulação da relação intencional do pensar ao objecto, ela está já configurada por uma categorialidade semântica própria que, com as suas formas, modela 0 plano intuitivo, prescrevendo ao objecto um sentido de apreensão, tornando-o um ver 'como' determinado.

$\mathrm{Na} \mathrm{IV}^{\mathrm{a}}$ das suas "Investigações Lógicas" vai então Husserl explicitar o elemento racional, ideal da linguagem, a sua intrínseca gramaticalidade de fundo, a título propedêutico como enquadramento do tratamento ulterior do estatuto do lógico-categorial. A meio caminho entre o objectivo e o subjectivo, o plano do ser e o do pensar, como explicitação que é do elemento formal do sensível, este último vai, na verdade, de algum modo resultar, como veremos, do encontro fecundo entre o plano intuitivo da percepção e a produtividade lógica do significar.

Prévio, por isso, ao nível categorial, concernente às condições formais de possibilidade do objecto em geral (identidade, não-contradição), a dimensão do significar, que a estrutura gramatical das línguas traduz, diz antes respeito às condições de um discurso com sentido (Sinn), isto é, em que a referencialidade a um objecto possível está garantida, por oposição ao discurso sem sentido (Unsinn), dela desprovido, e ao contrasenso (Widersinn), em que a significação se auto-destroi pela contrariedade dos termos em que consiste. ${ }^{43}$

O filósofo parte do princípio de que "[...] a língua, no seu material verbal, deve reflectir fielmente as significações possíveis a priori [...]”, devendo para isso dispor de formas gramaticais adequadas e disponíveis. ${ }^{44}$ Ora, uma distinção gramatical de fundo separa as formações linguísticas em dois grandes grupos distintos: é o das expressões independentes, ditas categoremáticas, tais como os nomes e os enunciados, e o das dependentes, as sincategoremáticas - tais como os prefixos e sufixos, adjectivos e advérbios, preposições, conjunções ou verbos - que só são significativas em união com outras partes

${ }^{43}$ Logisch. Unters., $2^{\circ}$ vol., IV ${ }^{\mathrm{a}}$ Inv., $§ 12$, pp. 326-328.

44 Ibid., §4, p. 305: “[...] die Sprache in ihrem verbalen material die a priori möglichen Bedeutungen getreu wiederspiegeln $[\ldots]$ ". 
do discurso. ${ }^{45}$ Ela reflecte uma clivagem profunda no domínio das significações entre aquelas que se reportam a representações simples de objectos e que, por isso, são completas e autónomas, e as que, sendo incompletas são também dependentes, quer dizer, só capazes de significar em ligação com outras significações, porquanto os conteúdos, as representações que traduzem só são expressivas enquanto partes de todos mais vastos.

Como no caso da composição dos objectos por partes, também aqui, no domínio das significações, nem tudo se liga com tudo, pois há regras para a construção sintáctica do discurso. São leis a priori de dependência funcional dos termos, que dizem respeito às espécies de relações possíveis entre categorias semânticas, às compatibilidades e incompatibilidades da sua articulação sintáctica, permitindo que as várias significações se combinem, transformem e unifiquem no interior da cadeia discursiva como sentido do mesmo referente, o visado pelo sentido total. ${ }^{46}$ A tarefa de uma gramática pura seria então, segundo o nosso autor, a de determinar o sistema 'a priori' das estruturas formais que regem a construção sintáctica do discurso nas várias línguas, ou seja, as formas primitivas de significações independentes e suas modificações possíveis por construção (a partir de tipos primitivos de conexão e de leis operatórias de combinação e transformação). ${ }^{47}$

Apesar de reconhecer uma certa objectividade à significação - "todas as significações primitivas, sem excepção, têm a sua 'origem' no recheio da intuição correlata" -, ${ }^{48}$ não há, segundo Husserl, reprodução desta por aquelas ou isomorfismo entre o plano da significação e o da intuição, recobrimento entre a articulação semântica e a intuitiva do campo fenomenal, como se a toda a expressão categoremática devesse obrigatoriamente corresponder um objecto independente. ${ }^{49}$ Com efeito, como atrás mostrámos, o que define a significação como intencionalidade é a consciência de generalidade que a anima, o seu reportar-se a qualquer coisa em geral, que tanto pode ser um objecto independente, de índole real e factual, como uma idealidade que nele se transforme por tematização e nominalização. Mas, como ali, também aqui, a propósito do excesso da significação sobre a intuição, o filósofo não se interroga sobre o fundamento ontológico possível dessa transcendência do intencional, sobre esse sentido de possibilidade, essa exigência de coerência que anima toda a construção da cadeia discursiva enquanto ela manifesta no fundo, por parte da consciência, um reportar-se à unidade e por ela aferir-se em todos os seus actos. Uma vez mais o reiteramos, porque para ele a sensibilidade é o paradigma de toda a intuição, a instância fundante de toda a doação em pre-

Conf. Ibid., $\S 5$, p. 305 e segs.
Conf. Ibid., $\S 10$, pp. $316-318$.
Conf. Ibid., $\S 14$, pp. $338-340$.

48 Logisch. Unters., VI ${ }^{\mathrm{a}}$ Inv., $§ 63$, p. 721: “[...] alle primitiven Bedeutungen überhaupt ihren 'Ursprung' haben in der Fülle korrelater Anschauung;"

49 Ibid., IV ${ }^{\mathrm{a}}$ Inv., $\S 8$, a), pp. 313-314. 
sença e o lugar próprio da verdade como evidência, é-lhe difícil encontrar a cobertura intuitiva indispensável para a validação de tudo o que, no conhecimento, excede propriamente o âmbito do factual. ${ }^{50}$

De modo que, como afirma na VI ${ }^{\mathrm{a}}$ 'Investigação Lógica”, “[...] o domínio da significação é muito mais abrangente do que o da intuição, isto é, do que todo o domínio dos preenchimentos possíveis." 51 "O paralelismo só pode e só tem de existir com respeito aos esquemas primitivos”, às significações simples e suas formas que, enquanto expressam algo de simples, têm um sentido real, não podem ser imaginárias. ${ }^{52}$ No que, porém, concerne as significações complexas, ou seja, toda essa multiplicidade ilimitada de significações unitárias que resultam de combinações de significações precedentes e que só tem como limite a esfera do sem-sentido, do disparate, elas carecem de "realidade" ou de "possibilidade." Com efeito, nenhum possível correlato unitário de preenchimento lhes pode corresponder, a não ser que se submetam ainda à regra da não-contradição formal e real, isto é, às leis do pensar próprio e adequado, mas esse é já o nível do lógico-categorial, em que, veremos como, uma intuição é possível, um correlato objectivo para a significação.

\subsubsection{As categorias: entre sentido e verdade}

A um primeiro nível, ainda apofântico, pode dizer-se que as categorias são essas formas e estruturas da significação que possibilitam a construção de um dictum válido, isto é, não apenas significativo mas verdadeiro, a que possa corresponder alguma coisa de objectivo, de existente. Emergindo da cadeia discursiva como um produto da função judicativa do entendimento, dos seus actos de articulação e relação, regimentando a formação dos enunciados e seus encadeamentos, elas vão mediar a relação intencional e intuitiva da consciência à realidade, permitindo a articulação cognitiva desta última numa série de objectidades ideais, estados de coisas possíveis, de grau crescente de abstracção e de complexidade, as quais vão constituir a sistemática aberta das ciências.

De apofânticas as categorias convertem-se em ontológicas, quando ao seu correlato objectivo é possível fazer corresponder, como recheio intuitivo, um conteúdo representante-apreendido (repräsentierenden aufgefassten

50 Na mesma linha de interpretação vai Heidegger, na leitura que faz da intuição categorial de Husserl, ao afirmar, por exemplo, no seguinte passo de "Seminar in Zähringen" de 1973, in Seminare, Gesamtausgabe, vol. 15, V. Klostermann, Frankfurt a. Main, 1986, p. 376: "[...] die sinnlichen Gegebenheiten geben den Massstab und das Kategoriale ist das, was den sinnlichen Daten entspricht. Die kategoriale Anschauung wird der sinnlichen Anschauung 'analog gemacht'”.

51 Ibid., VI ${ }^{\mathrm{a}}$ Inv., $§ 63$, p. 721: "Aber das Gebiet der Bedeutung ist sehr viel umfassender als das der Anschauung, d.i. als das Gesamtgebiet möglicher Erfüllungen."

52 Ibid.: "Nur in Hinsicht auf die primitiven Typen kann und muss der parallelismus bestehen, [...]." 
Inhalt $){ }^{53}$ A possibilidade do conhecimento a priori - em particular, da lógica pura enquanto, com as suas leis, ela funda e determina, a título arquitectónico, o sistema formal dos objectos e das teorias possíveis - depende, por isso então, não apenas da consistência formal das suas categorias e princípios, como pensava Kant, mas da comprovação fenomenológica da sua validade ontológica numa visão adequada das respectivas essências conceptuais. ${ }^{54}$

O filósofo vai então à procura, na segunda secção da sua VIa "Investigação Lógica", dos representantes-apreendidos das significações categoriais e propor, como solução para o problema, uma tese intermédia entre o realismo e o empirismo. Com efeito, como ali diz, as formas categoriais não são nem momentos dos objectos externos (características internas ou externas suas, como quer que sejam concebidas), nem dos internos, das vivências psíquicas do sujeito cognitivo (um conteúdo incluso em certos actos representativos, que a consciência reflexionante apreenderia por percepção interna deles). ${ }^{55}$ Elas apresentam-se, antes, como estruturas constituídas pelos actos relacionantes da função judicativa a partir da matéria de actos precedentes, constituindo, portanto, unidades de significação de grau superior. Produto e correlato de actos complexos de articulação e ligação de outros actos, a sua possibilidade objectiva ou realidade comprova-se ou confirma-se, "[...] sempre que a nova intenção se preenche adequadamente por meio da intuição subjacente [...]" aos respectivos actos fundantes, dando a ver num vincular relacionante de representações e como um objecto unitário o que neles há de comum. ${ }^{56}$

O cerne da tese de Husserl acerca da objectividade do categorial reside, portanto, na compreensão deste como um acto fundado, quer dizer, edificado sobre actos precedentes que, de grau em grau, de estrato em estrato, acabam por reenviar ao juízo de percepção, de experiência, em que a coisa, o objecto se dá, apresenta a si mesmo "em pessoa", sem mediações. ${ }^{57}$ Ora, a nós parece-nos que esta doutrina só colhe para as formas categoriais mais simples - as nucleares, directamente ligadas à percepção -, que se limitam a explicitar, e mesmo assim com uma grande margem de liberdade interpretativa, as sintaxes

53 Conf. Logisch. Unters., VIa Inv., § 53, p. 695.

${ }^{54} \mathrm{O}$ intento de fundamentação fenomenológica da lógica pura motiva todo o programa teórico das "Investigações Lógicas", como fica bem claro pela leitura dos primeiro e último capítulos do seu primeiro volume. Com efeito, nos "Prolegómenos à Lógica Pura"esta disciplina é proposta como doutrina da ciência, fundamento da sua unidade teorética e da sua objectividade, na condição de poder legitimar, com o auxílio da fenomenologia, a origem dos seus conceitos na intelecção ideativa e intuitiva das essências correspondentes. Veja-se, a este propósito, Op. Supra-cit., cap. XI, §67.

55 Conf. Logisch Unters., VI ${ }^{\mathrm{a}}$ Inv., $\S \S 43-44$.

56 Ibid., $\S \S 51$ e 41, p. 663: "Und wo sich die neue Intention durch unterliegende Anschauung adäquat erfüllt, erweist sie ihre objective Moglichkeit bzw. Die Möglichkeit oder 'Realität' des Allgemeinen."

57 Conf., por exemplo, Formale und Transz. Logik, $\S 86$ e segs., onde se defende a originalidade do juízo de experiência e o seu enraizamento na percepção como fundamento de todas as construções sintácticas superiores. 
já implícitas na esfera ante-predicativa da percepção. Já, porém, no que concerne as categorias sintácticas, em que por ideação e abstracção formalizante novas idealidades são constituídas e enlaçadas por necessidades de carácter sintéctico e analítico, tal perspectiva não satisfaz, pois não dá conta suficiente do lugar de proveniência do "lógico", ou seja, do analítico-formal. Com efeito, como também viram os medievais com o seu conceito normativo de "transcendental" ou Kant com o de "ideia"enquanto pólo unificador do conhecimento, não é abaixo mas acima dele, ao nível do intelecto ou da razão, que o entendimento judicativo, no seu poder quase ilimitado de composição formal de objectos de grau crescente de complexidade, pode colher o critério e a medida de aferição para a construção das suas sínteses. ${ }^{58}$ Ele reside nessa exigência formal de invariância e unidade que, em Husserl, a categoria formal fundamental de "objecto em geral" consigna enquanto expressiva da ideia mesma de possibilidade. Explicitemos então o nosso ponto de vista, acompanhando passo a passo o filósofo a propósito dos três tipos de categorias por ele consideradas na exposição e fundamentação da sua tese.

O primeiro tipo de categorias, o mais simples, é aquele que se reporta directamente à experiência ante-predicativa e tem como seu acto fundante a percepção, em que as coisas são dadas como um todo, de uma só vez e de um modo simples. ${ }^{59}$ São as categorias-substrato, nucleares ou objectivas, produto de actos de articulação e relação, que explicitam a estrutura interna dos objectos (segundo o esquema predicativo da relação entre a parte e o todo) e suas relações recíprocas em conjuntos, unidades mais abrangentes. ${ }^{60}$ Embora não constituam determinações reais dos objectos, mas meras formas possíveis de os apreender e ligar, retiradas da morfologia das significações, a sua validade objectiva pode, contudo, sempre ser comprovada pelo confronto com os conteúdos sensíveis dos objectos enquanto eles perfazem o recheio da matéria, do sentido de apreensão das percepções fundantes. Na verdade, embora haja uma diversidade de modos de interpretar os conteúdos da experiência sensível, nem tudo pode ser dito sobre tudo ou se conforma a tudo, a última palavra devendo mesmo ser dada aos objectos. Husserl chega mesmo a partilhar o ideal logicista de uma linguagem rigorosa, constituída por significações unívocas e conformes às determinações dos objectos. Seja como for, o que aqui agora importa salientar é que, com esse primeiro estrato categorial, novas objectidades são constituídas - estados de coisas, colecções, conjuntos - que, uma vez

58 Veja-se, por exemplo, São Tomás de Aquino, Suma Teológica, 1. q.16 a.5, B.A.C., Madrid, 1964 , p. 643, onde refere o intelecto divino como "[...] mensura et causa omnis alterius esse et omnis alterius intellectus"; e Kant, Kritik der reinen Vernunft, A 327-328, Suhrkamp, Frankfurt, 1974, p. 331: "Ich verstehe unter der Idee einen notwendigen Vernunftbegriff, dem kein kongruierender Gegenstand in dem sinnen gegeben werden kann." 
nominalizadas, se podem tornar membros-sujeitos de novos actos categoriais. $^{61}$

Há, porém, dois outros estratos de formas categoriais, edificados já não directamente sobre a percepção do individual, mas sobre a intuição de generalidades: são as categorias mistas, que excluem tudo o que é individual, e as puras, que a isso acrescentam a exclusão de todo o conteúdo sensível.

Comecemos pelas primeiras. Elas fundam-se na abstracção ideativa da "species", que considerámos atrás, e articulam as essências entre si, unificando-as segundo relações de compatibilidade/incompatibilidade de seus conteúdos. ${ }^{62}$ Expressando leis e necessidades sintécticas a priori dos objectos da experiência externa ou interna, elas constituem-se em torno dos diferentes géneros concretos mais gerais de objectos, constituindo a base das ontologias regionais. ${ }^{63}$ Como conceber neste caso a sua validade ontológica, pergunta-se o filósofo, se não há qualquer coisa como um "intelecto puro", uma "faculdade"do puro pensar sem uma base fundante sensível? ${ }^{64}$ A resposta encontra-se, a seu ver, na definição do acto categorial como um acto fundado, isto é, edificado sobre a matéria de seus actos fundantes. Assim, como para o primeiro género de categorias, também aqui, nas categorias sintácticas, a sua adequação como síntese depende funcionalmente da adequação das intuições fundantes. Ora, o que nos é dado nestas são exemplos concretos, reais ou imaginados, de relações entre objectos individuais. Eles servem de ponto de apoio e substrato funcional para a realização abstractiva e intuitiva das categorias. ${ }^{65}$ Com efeito, concomitantemente à evidência de seus representantes-apreendidos, dá-se por abstracção do momento individual e analogia a visão sintéctica global adequada da relação categorial como uma generalidade, uma objectividade de grau superior. ${ }^{66}$

E no entanto, perguntamos nós, se a intenção significativa categorial não é directamente preenchida na sua generalidade por uma intuição intelectiva directa da forma categorial, mas apenas confirmada na sua possibilidade objectiva pelos casos individuais considerados, com que legitimidade reclamar então para ela mais do que a generalidade presuntiva do empírico, outorgar-lhe, como faz Husserl sem reticências, a apodicidade do a priori? Reiteramos aqui a pergunta que fizemos a propósito da intuição eidética: o que é que legitima passagem da existência à essência, do ente ao ser, do múltiplo ao uno senão a visão, a intuição intelectual previa da unidade como instância fundante

Conf. Ibid., $\S \S 49$ e 51.

${ }^{62}$ Conf. Ibid., $\S 52$ e pontos 4.2. e 4.3. deste nosso estudo.

${ }^{63}$ Conf. Ibid., III Inv., § 11.

${ }^{64}$ Conf. Ibid., VI Inv., $§ 60$.

${ }^{65}$ Conf. Ibid., $\S 52$ e $\S 58$, p. 706: "So kann das intuitive Allgemeinheitsbewusstsein nicht bestehen ohne unterliegende individuelle Anschauung, eine Identifikation nicht bestehen ohne unterliegende Akte in betreff der identifizierten Objekte usw." 
de toda a racionalidade, que Husserl todavia não considera? É esta pré-compreensão que constitui a fonte de legitimação da aprioridade, como reconheceu Heidegger com toda a tradição intelectualista e platónica. Porém, Husserl quer colher as vantagens epistemológicas e lógicas do apriorismo, sem abdicar do pressuposto empirista do primado ontológico do dado sensível, o que, à semelhança do que sucedera à gnoseologia de Kant, não pôde deixar de o conduzir a um certo número de dificuldades e inconsequências, entre as quais a do dualismo entre forma e conteúdo, como veremos pela sua análise do terceiro e mais abstracto tipo de categorias, o analítico-formal.

Conceitos puramente categoriais - tais como unidade, pluralidade, relação, conceito - concernam o elemento formal da proposição, isto é, o seu valor de verdade, qualquer que seja o seu conteúdo. Edificados sobre actos já fundados - unidades intuitivas de teor já categorial mas ainda concreto -, eles constituem-se em novos actos relacionantes e ideativos de teor abstractivo superior, porquanto apenas atendem à forma categorial do objecto, excluindo "de seu teor intencional, não somente tudo o que é individual, mas também tudo o que é sensível."67، "Abstracção formalizante" é a designação que dá a essa operação de destacamento da forma do objecto, categorialmente enformado como um todo, relativamente a todos os seus componentes sensíveis. Assim, se a abstracção se fundar na intuição concreta de uma relação entre essências, então a consciência de abstracção dirige-se para a forma da relação na sua especificidade, excluindo da sua consideração o teor material de seus membros. ${ }^{68}$

O categorial concerne, assim, o lógico na proposição, ou seja, o tipo de enlace relacionante que une, em cada caso, os seus membros correlativos e recíprocos num todo significativó, quaisquer que sejam as variações introduzidas no seu conteúdo, enquanto na sua generalidade e indeterminação eles se deixam reger por simples leis analíticas. ${ }^{69}$ Sinifica isto, na perspectiva de uma interpretação extensional do juízo herdada das reflexões de Bolzano e de Frege sobre a lógica matemática e a analiticidade, que o sentido lógico da proposição, o género de enlaçe que a cópula "é" estabelece, em cada caso, entre o sujeito e o predicado não depende de considerações do seu conteúdo - esse era o ponto de vista da compreensão ainda partilhado Kant em consonância com a tradição - mas do puramente formal nela, que se obtém pela substituição de seus termos por variáveis. ${ }^{70}$

67 Conf. Ibid., §60, p. 713: “[...] allgemeiner Anschauungen, wlche nicht nur alles Individuelle, sondern alles Sinnliche aus ihrem intentionalen Gehalt ausschliessen."

68

69 Conf. Logisch. Unters., III Inv., § 11, pp. 251-254.

70 Conf. $\S 12$, p. 255: "Analytisch notwendige Sätze, so können wir definieren, sind solche Sätze, welche eine von der sachlichen Eigenart ihrer [...] Gegenständlichkeiten und von de rev. Faktizität des falles, von der Geltung de rev. Daseinssetzung völlig unabhängige Wahrheit haben; also Sätze, die sich vollständig 'formalisieren' [...] fassen lassen." Sobre o sentido de analiticidade em Husserl e seus antecedents lógico-filosóficos, veja-se o estudo de 
Ora as formas categoriais, para poderem ser ontologicamente válidas, isto é, não apenas significativas, mas expressivas de possibilidades, modos de ser do objecto em geral, seus predicados e relações, não resultam indiferentemente de qualquer tipo de combinação entre os membros do juízo, mas estão sujeitas a um conjunto restrito de possibilidades e impossibilidades combinatórias. São elas as leis puras do "pensar propriamente dito", que determinam no plano formal o leque idealmente limitado de transformações possíveis que uma forma categorial dada pode receber, uma vez pressuposta a identidade de seus membros. Regendo a ligação dedutiva dos objectos entre si, elas apenas determinam, tipos possíveis de teorias e suas relações, constituindo por isso o operador essencial desse sistema de objectos possíveis que configura, para Husserl, o modelo de uma ontologia formal enquanto correspondente fenomenológico desse ideal teorético da "mathesis" que é, a seu ver, para Husserl, a doutrina das multiplicidades. ${ }^{71}$

Qualquer intuição categorial (mesmo imaginária) serve de fundamento e de ponto de apoio à percepção adequada da verdade dessas leis, uma vez que elas são indiferentes ao teor do material que regulam sem prescrever no que e como da sua concretude. Com efeito, a sua evidencia patenteia-se fenomenologicamente à simples efectuação das sínteses e restantes actos categoriais correspondentes como o facto mesmo da razão, a essência ideal do entendimento enquanto este, nas espécies e formas de seus actos judicativos, se reporta e enuncia algo que pertence à estrutura, à configuração essencial do ente. $^{72}$

Para Husserl, a simples constatação e elucidação fenomenológica dessa concordância entre o pensar e a realidade, as leis do entendimento e o curso da natureza, bastam para esclarecer de forma satisfatória o problema do conhecimento, sem ser necessário enveredar por teorias e explicações metafísicas de teor mais incerto e conjectural. ${ }^{73} A$ priori formal e material analítico e sintéctico defrontam-se, assim, na sua dualidade como um dado fenomenológico último e intransponível, o facto mesmo do conhecimento, de que é afinal possível dar conta na sua possibilidade, mas nunca explicar na irredutibilidade última da sua raiz metafísica.

J. Benoist, Phénoménologie, Sémantique, Ontologie. Husserl et la Tradition logique. austrichienne, "Épimethée", P.U.F., Paris, 1997, p. 54 e segs.

${ }^{71}$ Sobre a doutrina das multiplicidades, veja-se do autor, Logisch. Unters., $1^{\circ}$ vol., Prolegomena zur reinen Logik, $11^{\circ}$ cap., § 70, pp. 248-251 e Form. und Transzend. Logik, $1^{\text {a }}$ sec., III ${ }^{\circ}$ cap.

Logisch. Unters., VIa Inv., § 64, p. 727: "Die reinen Gesetze aber sind rein eben vom matter of fact, sie besagen [...] was schlechthin allem Brauch und allen Abgrenzungen nach Realitätssphären entzogen ist, und es darum ist, weil es zur essentiellen Ausstattung des 


\subsection{Sínteses activas e construção do conhecimento}

Validada nos respectivos actos intuitivos a componente eidética e categorial da significação, de que depende afinal a aprioridade do saber na sua universalidade e necessidade, estão reunidos os elementos para a descrição fenomenológica do conhecimento como um processo faseado de objectivação do dado empírico através de um encadeamento teleológico de actos sintéticos. ${ }^{74}$

O ponto de partida é, como vimos anteriormente, a pré-doação passiva do objecto individual à percepção a partir de um plano de fundo, de um horizonte. Na sua imediatez, em que ainda não há diferenciação de partes nem recognição no conceito, ele apresenta-se já contudo como um todo articulado de aspectos e momentos, a unidade de uma síntese abarcante, que pode a todo o momento ser explicitada por actos de grau superior de consideração. Ora, tal acontece porque ao nível da percepção, na associação e entrefusão dos seus actos constituintes, já intervém uma consciência sintética de identidade, ou seja, o visar intencional de um algo indeterminado aí presente e constante em todas as variações possíveis do seu aparecer. ${ }^{75}$

É essa forma ideal de unidade que permite à consciência num segundo momento, através de uma variação qualitativa do seu acto, converter o objecto percebido em unidade temática intencionada, substrato de propriedades que vão surgindo como determinações suas. ${ }^{76}$ Inicia-se então um processo escalonado de objectivação em que a coisa, anteriormente percebida como um dado imediato num acto simples e fundante, é primeiro explicitada nos seus constituintes, depois reconstruída significativamente em actos categoriais. Graças às sínteses activas, ela aparece então à consciência com nova configuração, como um todo estruturado de elementos interdependentes, que por sua vez se apresenta como parte de um todo mais abrangente. Deste modo se altera a relação da consciência à realidade: objectos, originariamente constituídos de modo passivo pela sensibilidade e que aí estavam num único grau de acto, são agora, diz-nos o filósofo, "[...] submetidos à necessidade de terem que se constituir multirradialmente em actos de grau superior, os quais constituem os seus objectos por meio de outros objectos que de per si já são constituídos em outros actos."

${ }^{74}$ Conf. Husserl, Aktive Synthesen: Aus der Vorlesung "Transzendentale Logik" 1920-21, (Husserl., XXXI), Kluwer Acad.Public., 2000, que citaremos na tradução port. de C. Morujão: Sinteses Activas. A partir da Lição "Lógica Transcendental" de 1920-21, in Obras de Husserl, Centro de Filos. da Univ. de Lx., Lx., 2005, $4^{\circ}$ cap., § 6, pp. 76-77. Ibid., $1^{\circ}$ cap., § 4, pp. 24-27.

76 Ibid., § 5, p. 30 e Erfahrung und Urteil, $1^{\text {a }}$ sec., cap. 2, § 24, a), p. 124 e segs.

77 Logisch. Unters., $2^{\circ}$ vol., (Husserl., XIX/2), VI Inv., $2^{\mathrm{a}}$ sec., $6^{\circ}$ cap., $\$ 46$, p. 674: “[...] der Notwendigkeit, sich vielstrahlig in Akten höherer Stüfe konstituieren zu müssen, die ihre Gegenstände mittels anderer, in anderen Akten für sich bereits konstituierten Gegenstände konstituieren". 
A forma sintáctica do juízo, por que se efectiva uma análise e correlação das partes/propriedades do objecto, é o operador de toda a objectivação que comanda a ideia mesma de cientificidade. Explicitando o elemento essencial do sensível, ela pode mesmo, por ideação, universalizá-lo e formalizá-lo segundo variáveis, expressando-o num enunciado de generalidade como uma unidade multifacetada de múltiplas realizações constitutivas. ${ }^{78} \dot{E}^{\text {este }} \mathrm{o}$ procedimento próprio de um conceber já científico, em que o objecto, formalizado, se apresenta como uma estrutura a integrar num conjunto mais vasto de estruturas e a compreender a partir de uma teoria universal das partes e do todo, do conteúdo e do continente. ${ }^{79}$

Constituiem-se assim, através de sínteses activas de identificação que são uma criação progressiva de sentido, objectividades de grau superior, expressivas de estados de coisas reais que, por um processo de nominalização substantiva que não altera o seu sentido de apreensão, se podem por sua vez converter em sujeitos ou membros de novos juízos. Estes podem, por seu turno, tornar-se substratos de novas predicações, de acordo, aliás, com as leis protensionais da consciência, a sua orientação teleológica, num processo idealmente infinito de enriquecimento gradual do sentido que visa fazer jus à estruturação em rede do real.

Husserl distingue, assim, entre os substratos absolutos, autónomos, da percepção e os nominalizados, ou seja, aqueles que surgiram de determinações anteriores de juízos prévios. ${ }^{80}$ Nos dois casos actua a informação categorial, ou por formação intelectual de uma matéria pré-dada ou por transformação lógica de uma matéria já formada categorialmente. Toda a objectividade categorial ou de entendimento, ou seja, que é o produto de uma síntese activa de múltiplos membros, passa, deste modo, por dois estádios sucessivos de objectivação: um primeiro em que a unidade noética de uma consciência operativa pré-constitui um colectivo através de uma série de actos sucessivos; um segundo em que o conjunto é recaptado como objecto identificável para o eu. ${ }^{81}$

A nominalização apresenta-se, assim, como esse procedimento essencial do entendimento lógico que permite à consciência sintéctica global, quando um novo objecto se lhe apresenta como tema primário de atenção, reter aquilo que foi apreendido do tema como pertencendo ao mesmo conjunto, de forma

78 Conf. Sinteses Activas, $4^{\circ}$ cap., $\S 17$, c), p. 89 e Erfahrung und Urteil, $3^{\mathrm{a}}$ sec., caps. 2 e 3.

79 Conf. Sinteses Activas, $3^{\circ}$ cap., $\S 11$, p. 58 e $4^{\circ}$ cap., $\S 16$, pp. 78 e segs.

80 Ibid., $3^{\circ}$ cap., $\S 10$, p. 49 e segs. e apend. VI, p. 101, onde afirma: "Se tivermos já um qualquer substrato, a sua determinação explicitativa pode ser autonomizada, tornar-se ela própria novamente em substrato e, se quisermos, em substrato principal autónomo para determinações posteriores, que se deixam desligar do interesse pelos substratos anteriores."

81 Ibid., $3^{\circ}$ cap., $\S 12$, p. 61: "Cada objectividade engendrada sintecticamente a partir do Eu, por conseguinte de múltiplos membros, tem dois estádios constitutivos. [...]. Em especial: o coligir é uma realização sintéctica, por meio da qual, de forma essencial, um colectivo é pré-constituído. Ele transforma-se em objecto temático através de uma recaptação, [...] com o qual, apenas, o conjunto é dado como objecto, como identificável para o Eu." 
que, com a modificação noemática, não se altere o núcleo temático, haja um aprofundamento do sentido - acompanhado, do lado noético, pela forma total de articulação e identificação dos actos por teses e sínteses -, e não uma infirmação ou contradição do anterior. ${ }^{82}$

Assim, através de uma transformação contínua do dado, um visar mais além, uma sequência de intenções parciais fundidas na unidade de uma intenção global, a vida da consciência racional apresenta-se como uma síntese multi-estratificada de objectos e de tipos objectais segundo a estrutura da subsumpção da parte pelo todo, ou seja, como uma dinâmica de constituição racional que tende para a auto-doação intuitiva última do mundo como horizonte derradeiro do seu intentar. Campo universal em que se dão os objectos e em que se inscreve, a título de pressuposto, a experiência da consciência, o mundo (Welt), como totalidade sintéctica, consigna também, com efeito, para Husserl o correlato universal da vida operatória da consciência para que remetem todas as suas sínteses - uma ideia (Idee), de sentido infinito, da unidade ideal de toda a realidade, antecipada pela razão universal como seu $a$ priori universal último. $^{83}$

\section{O horizonte da racionalidade}

\subsection{Da síntese passiva à constituição originária do tempo: o empirismo transcendental de Husserl}

O idealismo da constituição, a que chegara Husserl nas "Ideen I", defronta-se, já a nível da percepção, com a opacidade dos dados hiléticos. São impressões, sensações de vária ordem, a que a consciência tem de dar forma, unir em torno de alguma coisa de permanente, a que possa reportar-se na predicação. ${ }^{84}$ Elas exigem uma elucidação fenomenológica radical até porque questionam a tese, ali defendida, de que a consciência transcendental é a fonte absoluta da doação de sentido. ${ }^{85} \mathrm{~A}$ investigação da hylé vai, no entanto, - com a descoberta de uma mais profunda constituição do eu e do tempo, a partir de

82 Conf. Ideen I, $3^{\text {a }}$ sec., $4^{\circ}$ cap., $§ 122$, p. 301: “[...] das neue tematische Objekt erfassend, oder vielmehr ein neues Glied des Gesamtthemas als primares Thema erfassend, aber das vorher gefasste Glied, als zum selben Gesamtthema gehörig, noch haltend.” Veja-se ainda, sobre o mesmo, Form. und Transc. Logik, $1^{\text {a }}$ sec., $4^{\circ}$ cap., $§ 42$, pp. 98 e segs.

Conf. Erfahrung und Urteil, introd., § 7, pp. 23-25 e §9, pp. 36-37. E ainda, Krisis, $3^{\mathrm{a}}$ p., $\S 38$, p. 147, onde afirma: "Welt ist das Universalfeld, in das alle unserer Akte [...] sind." E, mais adiante, sobre o mesmo, p. 148 pode ler-se: "[...] Welt als Korrelat einer erforschbaren Universalität synthetish verbundener leistungen ihren Seinssinn und ihre Seinsgeltung in der Totalität ihrer ontischen Strukturen gewinnt."

85 Ibidem, § 55, p. 134: "Sinneseinheiten setzen [...] sinngebendes Bewusstsein voraus, das seinerseits absolut und nicht selbst wieder durch Sinngebung ist." 
uma fonte radical misteriosamente evocada - conduzir, uma vez mais, o filósofo à alteração do seu ponto de vista filosófico, desta vez no sentido de um empirismo transcendental.

Com efeito, a matéria sensível da percepção releva da síntese passiva do sentir, que é essa camada primária da experiência, em que a intencionalidade, receptiva e ainda inconsciente, funciona de um modo automático por um mecanismo de associação e entrefusão de actos sensíveis. ${ }^{86}$ Assim, se a percepção se apresenta como regular e coerente na síntese que perfaz das sensações, é porque estas não se apresentam como caóticas mas como um tecido homogéneo e contínuo, em que grandes diferenças ressaltam, em particular entre um elemento central e um horizonte neutro.

Porém, a sensação, a apreensão de algo indeterminado a partir de um campo sensível, o seu destacamento e pré-doação posicionais só são possíveis porque actos singulares se sucedem em cadeia numa síntese de identificação continuada, formando uma unidade politética de instâncias e momentos impressivos. Mas isto é o mesmo que dizer que a síntese passiva releva do tempo, que a experiência do sentir tem como condição da sua unidade a consciência interna do tempo. ${ }^{87}$ Esta, que é a forma primária da síntese, não estando no tempo, constitui-o como fluxo, não só porque é, como nunc stans primordial, a fonte imutável do seu brotar, mas porque imprime à sucessão dos momentos a regularidade, a constância da forma, da igualdade consigo, que é um referir-se e retomar-se no presente através de um tender para o futuro. Uma intencionalidade longitudinal perpassa assim a intenção transversal das ekstases temporais unindo as várias fases do devir, da duração imanente do já aí presente, de molde a constituí-lo como o fenómeno, a matéria ou o substrato inesgotável da actividade constituinte da consciência transcendental. ${ }^{88}$

Mas Husserl, na radicalidade que caracteriza o seu pensar, ainda não está satisfeito com esta sua leitura da génese da experiência; intenta ir mais longe; recuar até ao "ponto-fonte originário" em que aparecente e aparição, sentente e sensível são o mesmo na unidade indiscernível do seu aparecer. ${ }^{89}$ É que a consciência interna do tempo, na regularidade da forma em que consiste, já releva do constituído, tendo por isso de ser o produto de uma origem mais radical, a saber, aquela que se prende com a constituição originária (Urkonstitution) do próprio tempo.

${ }^{86}$ Conf. a obra póstuma de Husserl, Analysen zur passiven Synthesis (Husserl., XI), Kluwer Academic Publishers, 1966.

87 Conf. Ideen I, $\S \S 81-83$, pp. 196-202.

${ }^{88}$ Husserl, Zur Phänomenologie des inneren Zeitbewusstseins (1893-1917), (Husserl. X), § 39, p. 81: "So geht also durch den Fluss eine Längsintentionalität, die im Lauf des Flusses in stetiger Deckungseinheit mit sich selbst ist."

89 Veja-se Ibidem, § 36, pp. 74-75 e o estudo de T. Ullmann, La Génese du Sens, L'Harmattan, Paris, 2002. 
Assim, nos aditamentos às suas célebres "Lições" sobre o tempo, o tempo é apresentado como um acontecimento originário (Urgeschehen) pré-egológico, de onde emerge o ego e o seu pólo-objecto, o agora primordial que se temporaliza originando o fluxo dos momentos. Constituinte, não constituído, ele é o absoluto que se auto-funda no anonimato, embora, da sua espontaneidade emergente.

Vemos, deste modo, que de novo as condições da unidade da experiência possível remontam para uma mais originária instância, a qual agora se determina como uma condição pré-consciente e, por assim dizer, animal do espírito - a de uma impressão originária, de uma arqui-hylé sensível que, pelo modo como se auto-afecta e desdobra, engendra a unidade já activa e significativa da morphé intencional. ${ }^{90} \mathrm{~A}$ esta luz, como instância originante e constituinte, o tempo aparece então como a "película"impressionável de um presente, de um agora pulsante - esse que a corporalidade (Leib) consigna como vida -, de onde brota em blocos de duração singular tudo o que dura. Que tal suceda, no entanto, na forma já teleológica de uma experiência regular e homogénea é o que o filósofo tem de pressupor de forma a poder garantir a unidade da experiência e, com ela, a possibilidade do conhecimento. Interpreta, assim, a temporalidade, não como a fonte, sempre em aberto, de temporalizações diversas do sentido, mas como a forma imutável de uma estrutura auto-regulada estável e atemporal.

\subsection{A reinterpretação do a priori: balanço da filosofia do conhecimento husserliana}

É tempo de ir concluindo, de fazer um balanço da gnoseologia husserliana. Ela parte, como vimos, do problema do conhecimento a priori, que é aquele que se reporta à estrutura essencial do objecto, suas propriedades e relações, e as explicita sob a forma de conceitos ou leis apodícticas. Pela sua universalidade, que abrange o ser ideal e real, e a sua necessidade, aquele distingue-se do conhecimento empírico, que só concerne o individual contingente e se apresenta como ontologicamente secundário.

Crítico do psicologismo e de toda a forma de relativismo, que considera contrário ao sentido próprio da ciência e da moral, o filósofo começa por validar o a priori, destacando, pelo método das variações, a sua idealidade, ou seja, apodicidade, da generalidade meramente presumptiva do empírico. A sua abordagem fenomenológica em particular, adversa a todo o reducionismo ou construtivismo artificial, permitiu-lhe, nas "Investigações Lógicas", descrever o domínio complexo e variado do a priori, desde o plano empírico-material ao analítico-formal. E no entanto, apesar disso, o primado hermenêutico que ali concedia à significação dos actos sobre a referência objectiva conduziu-o, 
como vimos, do realismo do inteligível à proximidade de Kant e, deste - no intento de superar o seu formalismo -, às paragens de um empirismo transcendental, já tangente ao sensualismo, onde a normatividade do a priori se perde, assim como a possibilidade de justificar de forma convincente a sua objectividade.

Assim, recusando como idealizante toda a hipostasiação do elemento ideal da experiência, vai o autor das "Ideen" reinterpretá-lo, agora já de um ponto de vista genético-temporal, como inseparável do movimento em que é formado por operações práticas de constituição e de verificação. ${ }^{91} \mathrm{E}$ com isso tudo se altera.

O problema da ciência, que se lhe apresentara anteriormente como sendo o da fundamentação da mathesis enquanto teoria pura das multiplicidades ou das formas possíveis de teorias, converte-se agora na questão da relação do lógico-formal com a intuição, tal como esta, pela percepção, se enraíza no mundo da vida (Lebenswelt). ${ }^{92}$ É que a vida sensível constitui, doravante para ele, o fundamento contingente de todo o sentido de verdade: o campo fenomenal já não se determina como um sistema de idealidades essenciais, mas como um a priori espácio-temporal de onde brota, por idealização, o a priori matemático ${ }^{93}$ e a supra-temporalidade deste, agora entendida como mera omnitemporalidade, é vista como um modo de temporalidade em que o objecto se apresenta como idêntico nos vários actos. ${ }^{94}$

O subjectivismo desta última perspectiva, apesar de atenuado pela teleologia do intencional e pela intersubjectividade do sentido compartilhado, é, todavia, insuficiente, pensamos nós, para legitimar de forma convincente a objectividade do conhecimento, pois esta inclui como sua componente essencial a concordância com a esfera ôntico-real. Falta-lhe, para isso, o mais importante, a saber, o solo, o substrato ontológico, que só um retorno são ao realismo poderia restituir.

Com efeito, como salientou Husserl, conhecimento a priori e a posteriori progridem através de uma dialéctica de perpétuo ajustamento entre o conjectural e o experimental, sendo que em ambos se verifica uma transcendência do objecto sobre o conhecimento, quer do visado sobre o dado, quer do dado sobre o visado. Ora, o conhecimento a priori só é possível se o sujeito for capaz de apreender em si, por uma espécie de evidência interna, de intuição intelectual que não tem de passar pela mediação empírica do facto, conexões essenciais do real que se reportam a um estado de coisas possível. É o que sucede com a matemática, que é o exemplo típico de um tal conhecimento com a pretensão a uma validade ontológica: prescindindo de prévios objectos

91 Veja-se, por exemplo, Formale und transz. Logik, ed. ref., $2^{\mathrm{a}} \mathrm{sec} .3^{\circ}$ cap., pp. 162 e segs.

92 Sobre a mathesis, veja-se, por ex., Ibidem, $1^{\mathrm{a}}$ sec., § 52, pp. 123-124. Sobre a Lebenswelt como solo originário da evidência, veja-se Die Krisis, III, § 34, d) e segs., pp. 130-137. 
empíricos, ela constrói, apenas com a consistência lógica de operações dedutíveis, estruturas finitas, definíveis a partir das leis de composição dos seus elementos, que a previsão científica comprova revelando a natureza matemática do real.

Cabe então perguntar como é possível a intuição imanente de uma objectividade real, senão porque a esfera ôntica do real vem já regida antecipadamente por uma esfera lógico-ideal, de que também fazem parte as matemáticas? Parece, assim, ter algum sentido afirmar - como fez Husserl de início que é porque o ser possui, de per se, uma estrutura inteligível e relacional, é porque se apresenta como lógos, que o pensar pode por sua vez antecipar, com credibilidade e êxito, o desconhecido a partir do conhecido. ${ }^{95}$

Como relevou Kant, os princípios do conhecimento a priori, que se estendem ao domínio do possível, permitem tal antecipação, conjecturando sobre objectos possíveis, realidades que permanecem problemáticas enquanto não forem dadas na experiência. Ora, na esfera ideal do conhecimento, como na sequência de Hegel sublinhou N. Hartmann, as categorias implicam-se mutuamente, estão inscritas numa rede de relações que, longe de serem construídas, são descobertas pela consciência e se, na aventura do conhecimento, muito permanece desconhecido ou porque ainda não foi conhecido ou porque é irracional, muito pode também ser deduzido e descrito com verdade por implicação de outros termos. ${ }^{96}$

Porém, Husserl, na interpretação que acabou por fazer da intuição categorial e em que confunde ou reduz as estruturas da objectividade às operações da consciência, privilegiou o pensar sobre o ser, distanciando-se definitivamente das terras promissoras da ontologia.

\subsection{Da fenomenologia a uma metafísica do conhecimento}

Porque Husserl, na leitura que fez da relação gnoseológica partiu, não do ser a que primeiro se reporta o intencional, mas do sentido e da questão da sua constituição subjectiva, em vez de ver naquele a origem da inteligibilidade que, de cada vez, ilumina e informa como sujeito a consciência intencional, buscou pelo contrário nesta, na estrutura e dinâmica dos seus actos, a fonte doadora de toda a verdade, resvalando, mesmo contra sua melhor intenção, para o idealismo e o subjectivismo. Por isso também, com a sua fenomenologia, as suas análises acerca da génese e constituição historial da racionalidade, abriu caminhos fecundos às ciências humanas - designadamente à psicologia, antropologia e ciências da linguagem -, mas não deu, a nossó ver, a boa res-

95 Veja-se a citação da nota 10 e Logische Unters., $1^{\circ}$ vol.: Prolegomena, $1^{\circ}$ cap., $§ 6$, p. 15 : "Die Systematik, die der Wissenschaft eignet, [...] erfinden wir nicht, sondern sie liegt in den sachen, wo wir sie einfach vorfinden, entdecken". E ainda, Ibidem, $11^{\circ}$ cap., § 65, a), p. 238. 
posta à questão, que era a sua, da justificação do conhecimento a priori. $\mathrm{Ou}$ melhor, aquela por que veio a decidir-se, de sinal contrário ao que era a orientação inicial da sua filosofia, - e que vê na imanência da vida sensível a origem de toda a transcendência do sentido e da objectividade - acabou por produzir um efeito também inverso ao que intentara com a sua reforma filosófica, acabando a sua fenomenologia por contribuir para a desconstrução do lógico, do apodíctico, e abrir caminho à hermenêutica e formas afins de contextualismo e historização da verdade. ${ }^{97}$

Reconhecendo a necessidade de um plano intuitivo puro, onde fundar a verdade do lógico-categorial - mas sem recuar, para lá do objecto transcendental, à esfera transobjectiva em que o ser se anuncia como o infinito -, o filósofo julgou poder obtê-lo por ideação a partir da percepção, sem ver que do real ao ideal, ao possível eidético, há um salto qualitativo em extensão e compreensão, que não era nem previsível nem necessário e que só a presença antecedente do próprio ser logra explicar.

Com efeito, como intentámos mostrar, apesar de as suas análises sobre a consciência - enquanto nas suas operações ela envolve generalizações e ideações de dados finitos - suporem de forma indirecta o infinito do ser como horizonte e "ideia reguladora" do conhecimento, nunca Husserl o abordou explicitamente ou reconheceu, a não ser na forma negativa de um infinito potencial, matemático - esse mesmo que é inerente à síntese imanente do tempo como série em aberto de momentos e que sustém a actividade constituinte do espírito.

Porém, a ideia kanteana de progresso do conhecimento que Husserl faz sua, só faz sentido, pensamos nós enquanto tarefa infinita da plena determinação do objecto transcendental no contexto realista de uma metafísica, em que a Transcendência, fundando a consciência, suprime o idealismo e torna ontológica a "ideia", mesmo se dela não assegura a visão adequada. Nesta perspectiva - que é num contexto dogmático a da filosofia clássica pré-kanteana e na contemporaneidade, já de um ponto de vista crítico e assumidamente apofático, a de um N. Hartmann, E. Lask ou, em menor grau, de Heidegger -, as categorias, os dados aprióricos, que resultam da participação da inteligência no Absoluto que a ilumina, são parte constitutiva de uma totalidade infinita e sistémica mais vasta e como tal devem ser interpretados. ${ }^{98}$

Inobjectivável porquanto indeterminado e inesgotável, o Ser infinito apresenta-se assim como a luz velada que ilumina o nosso intelecto, a raiz não-dual, absoluta da nossa consciência, que o entendimento lógico não capta

97 É bem conhecida a temática da destruição e da genealogia da lógica no período de Marburgo de Heidegger, que acompanha a elaboração da sua Fundamentalontologie. Veja-se, a propósito, os estudos de J. -F. Courtine em La Cause de la Phénoménologie, "Épimethée", P.U.F., Paris, 2007, $2^{\mathrm{a}}$ parte e a monografia de F. Dastur, Heidegger, Vrin, Paris, 2007.

98 Como introdução às filosofias destes autores, veja-se o excelente estudo de G. Gurvitch, Les Tendances actuelles de la Philosophie allemande, Vrin, Paris, 1949. 
mas supõe como seu modelo e referência. ${ }^{99}$ Se ele não é susceptível de ser dito ou enunciado, pode no entanto ser explicitado, descrito enquanto horizonte inefável do nosso pensar discursivo acerca de entidades finitas.

Foi o que reconheceu Descartes a propósito de Deus, com a sua distinção operatória essencial entre saber (savoir) e compreender ou conceber (comprendre, concevoir): o primeiro é um conhecimento intuitivo, uma apreensão imediata de realidades singulares por parte do intelecto; o segundo, um conhecimento discursivo e racional de essencialidades, uma explicitação analítica de suas propriedades e da lei da sua composição sintéctica. ${ }^{100}$ Com efeito, para ele, a realidade "objectiva" da ideia de Ser infinitamente perfeito não consigna de modo algum o produto de um entendimento finito; tem de ter a sua fonte mais acima, numa realidade "formal", isto é, real e actual infinita, que se apresente como matriz do pensar e sua luz ingénita, que ele actualiza no contacto com o exterior. ${ }^{101}$ Assim, se a experiência perceptiva põe em acto a intencionalidade da consciência, no entanto ela não a produz, decorrendo esta no plano já ideal e puro de um prévio horizonte a priori infinito e transcendente. É este então que, à partida, lhe serve de referência e critério em todas as suas operações, fornecendo ao entendimento finito o plano intuitivo ideal a partir do qual determina tudo o que vem ao seu encontro, define o seu tipo e antecipa o seu aparecer.

Numa palavra e para concluir, pensamos que foi a ausência de um enquadramento metafísico similar ao que acabámos de descrever que impediu Husserl de dar à sua fenomenologia o impulso e a orientação adequados ao preenchimento do lugar que de direito the cabe, como procedimento metódico, no âmbito de estudo das grandes questões filosóficas e que são as de teor ontológico e metafísico.

99 Reportamo-nos à doutrina da iluminação do intelecto pelo Verbo divino, reiterada, por exemplo, por Descartes na seguinte passagem de uma carta ao Marquês de Newcastle de 1648: "La connaissance intuitive est une illustration de l'esprit, par laquelle il voit en la lumière de Dieu les choses qu'il lui plaît lui découvrir par une impression directe de la clarté divine sur notre entendement, qui en cela n'est point considéré comme agent, mais seulement comme recevant les rayons de la divinité." (in Descartes, Oeuvres et Lettres, Gallimard, Paris, 1953, p. 1300.)

100 Descartes, "Carta a Mersenne" de 27 Maio 1630, in Ibid., p. 938: “[...] car comprendre, c'est embrasser de la pensée; mais pour savoir une chose, il suffit de la toucher de la pensée."

${ }^{101}$ Para a distinção entre realidade "objectiva" e "formal" da ideia em Descartes, veja-se, por exemplo, Ibid., $2^{\mathrm{a}}$ Respostas, pp. 390-391 e, para a passagem da ideia à sua causa, pp. 394-395 . 
